\title{
Spatial Analysis of Fiscal Balance Fund on Income Inequality in West Kalimantan
}

\author{
Amelia $^{1^{*}}$, Tri Diana ${ }^{2}$ \\ 1,2 STIE Indonesia Pontianak, Indonesia \\ 1amelamelia86@gmail.com, ${ }^{2}$ tridiana2904@gmail.com, *corresponding author
}

\begin{abstract}
The research aims to analyze the effect of fiscal balance fund on income inequality in West Kalimantan by considering spatial inter-relationships between existing districts/cities. The study showed that the Spatial Durbin Model with fixed effect was empirically suitable. A variant of spatial autoregression model using Gini Ratio during the period of 2010 - 2018 in 14 districts/cities of West Kalimantan. The study concludes that income disparities between districts/cities were low and constant or the income was relatively distributed per capita. Spatial interactions between districts/cities and their neighbors are also relatively low. Spatial aspect, fiscal balance fund and regional minimum wage have a significant negative effect. On the contrary, the industrial workforce, educated workforce and medical personnel do not affect income inequality in West Kalimantan. This study provides academics with the understanding of the importance of spatial dependence in income inequality model because the economic activity is always related to the neighbor.
\end{abstract}

Keywords: fiscal balance fund, income inequality, spatial aspect

\section{Analisis Spasial Dana Perimbangan Terhadap Disparitas Pendapatan Kalimantan Barat}

\begin{abstract}
Abstrak
Penelitian ini bertujuan menganalisis pengaruh dana perimbangan terhadap disparitas pendapatan di Kalimantan Barat dengan mempertimbangkan keterkaitan spasial antar kabupaten/kota yang ada. Studi ini menghasilkan pemilihan model spasial durbin dengan efek tetap secara empiris sudah tepat. Variansi dari model autoregresif spasial menggunakan Indeks Gini kurun waktu 2010-2018 silang tempat dari 14 kabupaten/kota di Kalimantan Barat. Hasil penelitian menyimpulkan disparitas pendapatan antar kabupaten/kota rendah dan konstan atau relatif merata dalam pendapatan per kapita. Interaksi spasial antar kabupaten/kota dengan tetangganya juga relatif rendah. Aspek spasial, dana perimbangan dan UMR secara negatif signifikan mempengaruhi disparitas pendapatan. Sedangkan tenaga kerja industri, tenaga kerja terdidik dan tenaga medis tidak mempengaruhi disparitas pendapatan di Kalimantan Barat. Penelitian ini memberikan wawasan bagi kalangan akademisi tentang pentingnya memasukkan spatial dependence kedalam model ketimpangan pendapatan karena proses kegiatan ekonomi selalu berkaitan dengan wilayah tetangga.
\end{abstract}

Kata kunci: dana perimbangan, disparitas pendapatan, aspek spatial

\section{INTRODUCTION}

Development in spatial scope is not always implemented equally. Some regions are able to realize rapid growth, while another region cannot reach the target because it has different sources. An investor tends to choose an urban area which has a complete supporting infrastructure and trained workforce. The development problem in spatial scope will identify the occurrence of inequality. 
Table 1. The Average Fiscal Balance Fund and Gross Regional Domestic Product (GRDP) per capita (constant), according to District/City in West Kalimantan Province, 2010-2018 (Central Bureau of Statistics of West Kalimantan Province, 2018)

\begin{tabular}{lllllllc}
\hline \multicolumn{1}{c}{ District/City } & \multicolumn{3}{c}{ Fiscal Balance Fund } & \multicolumn{2}{c}{ GDP/Capita } & \multicolumn{2}{c}{$\boldsymbol{\Sigma}$ Population } \\
\hline Sambas district & $\mathrm{Rp}$ & $942,462,879,702$ & $47 \%$ & $\mathrm{Rp} 19,429,046$ & $7 \%$ & 516,661 & $11 \%$ \\
Bengkayang district & $\mathrm{Rp}$ & $634,969,659,630$ & $32 \%$ & $\mathrm{Rp} 17,891,997$ & $6 \%$ & 233,466 & $5 \%$ \\
Landak district & $\mathrm{Rp}$ & $744,201,158,013$ & $37 \%$ & $\mathrm{Rp} 14,685,895$ & $5 \%$ & 351,875 & $7 \%$ \\
Mempawah district & $\mathrm{Rp}$ & $618,070,380,853$ & $31 \%$ & $\mathrm{Rp} 15,143,190$ & $5 \%$ & 248,290 & $5 \%$ \\
Sanggau district & $\mathrm{Rp}$ & $889,349,207,363$ & $44 \%$ & $\mathrm{Rp} 22,697,545$ & $8 \%$ & 437,195 & $9 \%$ \\
Ketapang district & $\mathrm{Rp} 1,237,634,079,430$ & $62 \%$ & $\mathrm{Rp} 26,426,205$ & $9 \%$ & 465,789 & $10 \%$ \\
Sintang district & $\mathrm{Rp} 1,017,144,414,013$ & $51 \%$ & $\mathrm{Rp} 17,961,354$ & $6 \%$ & 389,848 & $8 \%$ \\
Kapuas Hulu district & $\mathrm{Rp} 1,037,975,267,168$ & $52 \%$ & $\mathrm{Rp} 19,650,188$ & $7 \%$ & 240,820 & $5 \%$ \\
Sekadau district & $\mathrm{Rp}$ & $523,411,587,084$ & $26 \%$ & $\mathrm{Rp} 15,880,323$ & $6 \%$ & 191,123 & $4 \%$ \\
Melawi district & $\mathrm{Rp}$ & $665,366,252,402$ & $33 \%$ & $\mathrm{Rp} 12,933,215$ & $5 \%$ & 192,267 & $4 \%$ \\
Kayong Utara district & $\mathrm{Rp}$ & $487,245,639,248$ & $24 \%$ & $\mathrm{Rp} 17,718,405$ & $6 \%$ & 103,365 & $2 \%$ \\
Kubu Raya district & $\mathrm{Rp}$ & $830,976,780,896$ & $41 \%$ & $\mathrm{Rp} 24,277,994$ & $9 \%$ & 536,926 & $11 \%$ \\
Pontianak city & $\mathrm{Rp}$ & $739,747,035,190$ & $37 \%$ & $\mathrm{Rp} 30,991,967$ & $11 \%$ & 596,839 & $13 \%$ \\
Singkawang city & $\mathrm{Rp}$ & $526,785,490,388$ & $26 \%$ & $\mathrm{Rp} 24,329,126$ & $9 \%$ & 202,934 & $4 \%$ \\
\hline
\end{tabular}

The data on Table 1 shows that the local government tries to do the economic development in Ketapang, Sintang and Kapuas Hulu districts. However, it has not been able to decrease the income inequality in West Kalimantan. Pontianak city as the capital city of West Kalimantan province still has the highest Gross Regional Domestic Product (GDP) per capita, it has $11 \%$ of the average GDP per capita constant of all districts/cities in West Kalimantan. The economic activity concentrated in Pontianak city is relatively high which obviously influences the income inequality which tends to be faster than another district/city. The population growth which is continuously increasing into $13 \%$ also becomes one of factors. The income inequality generally can be seen from the different natural resources, demographic factor including workforce condition, development fund allocation between the regions either government or private investment, concentration of regional economic activity and mobility of goods and service (Hasna, 2013).

Spatial interaction using various research approaches and models to produce a more reliable research result. Regional income inequality and spatial impact as the effects of economic development have become significant and interesting problems especially to be the object of discussion by various literature reviews or researches. Reducing "spatial disparity" is an important agenda in the integration and development cohesion process. Cohesion explains to what extent the tolerance limit of the welfare disparity between regional and central area in a country is accepted socially and politically.

West Kalimantan ranks 17 of 34 provinces in Indonesia, and it becomes the first of five islands in Kalimantan in 2010-2018 with the average income inequality in the high category compared with another province. 


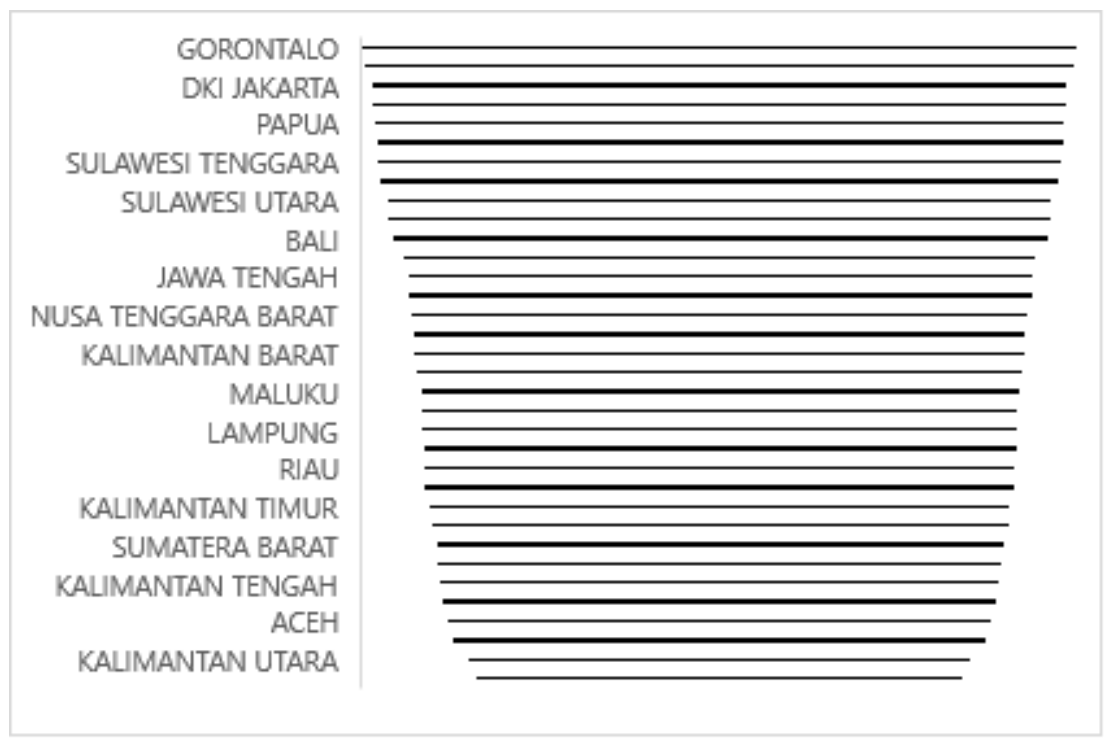

Figure 1. Income inequality (Central Bureau of Statistics of Indonesia, 2018)

Income inequality starts with the development spatial distribution according to the distribution of economic activities and population. Spatial aspect toward the increase of income inequality in every district/city in East Java, except Lamongan district. Fiscal balance fund has significantly shown positive impact on income inequality. Industrial workforce, medical personnel and minimum regional wage are another factor influencing it (Hasna, 2013).

Fluctuating income inequality requires central and local government to revise the applicable fiscal policy through the distribution of fiscal balance fund. The distribution of natural sources and taxes is inequal in all regions; therefore, the government provides general allocation fund for fiscal equalization and to reduce discrepancy between regions. The increase of income inequality is able to decrease social attachment (Nolan et al., 2017). Poor neighborhood urgently requires fund transfer from the central government, the investment expenditure will be hampered if it does not acquire sufficient fund (Johansson, 2016).

The study is related to the previous study discussing the effectivity of the central transfer in improving West Kalimantan's economy (Amelia \& Ekobelawati, 2019). The ineffectiveness seen in the distribution of General Allocation Fund (DAU) as it was given to Ketapang district which actually has the highest Revenue Sharing Fund (DBH). The government policy explicitly contradicted the theory. The highest value of Revenue Sharing Fund showed that the district had been able to maximize tax revenue and natural resources. The deceleration of economic development in Indonesia in 2012-2016 contributed to the increase of income inequality in district/city (Wardhana et al., 2018). The central transfer fund as fiscal balance fund between regions is expected to provide the improvement of regional development. Some other factors determining the change on inequality are industrial workforce, educated workforce and medical personnel as well as regional minimum wage. The location of a region determines the neighbor. The region which surrounded by prosperous neighbor will develop more rapidly than the region surrounded 
by poor neighbor. An analysis of income inequality considers spatial approach between districts/cities will produce a more precise conclusion than an analysis which ignores spatial relation. Therefore, the result will be used as a guideline for making the priority of development plan policy in order to reduce income inequality in West Kalimantan.

Fiscal balance fund can improve local revenue, especially urban area (Masaki, 2018). Although it decreases income inequality, there are still disparities among regions. Fiscal transfer distributed without considering the fiscal capacity and expenditure needs obstructs the potency of equality between the regions (Muñoz et al., 2016). The transfer of central government to regions does not have significant influence on income inequality. The income inequality has negative and significant influence on the allocation of central transfer fund in which the richest region acquires a higher income per capita (Leonel et al., 2016). There is a spatial linkage between districts/cities in Indonesia, and territorial convergence after regional autonomy applied. Furthermore, spatial simulation shows that random shock in Jakarta is not significant toward Indonesian economy (Aritenang, 2014). According to the aforementioned state of the art, the novelty of the study is the consideration of the spatial aspect in income inequality model, and the use fiscal balance fund variable as well as other factors. The best spatial model was chosen to analyze the influence of fiscal balance fund toward income inequality in West Kalimantan.

Fiscal balance fund is the sum of Revenue Sharing Fund (DBH), Special Allocation Fund (DAK), and General Allocation Fund (DAU). Revenue Sharing Fund comes from taxes revenue either income or management of natural resources in the relevant region. General Allocation Fund comes from the allocation of central government to regional government to cover local fiscal gaps. Special Allocation Fund comes from the central government allocation aiming to fund regional programs and activities which include in national priority and concern; thus, the fund is set by the government every year. A region which has a larger allocation of government investment tends to obtain a more rapid economic growth. The condition can promote regional development process by providing more employment and a higher income level per capita. The allocation of government investment to the region is highly determined by regional government system.

The decentralization of regional expenditure is more capable of creating income equalization than fiscal decentralization. The required conditions include the area of government business sector should be adequately large, the decentralization should be comprehensive which includes the redistributive government spending, and the expenditure decentralization should include the sufficient decentralization on the revenue aspect to make the local government depends on the local own-source revenue as the opposite of fiscal balance fund (Goerl \& Seiferling, 2014).

According to background of the study, the purposes of the study are to identify (1) the impact of spatial aspect on income inequality in West Kalimantan; (2) the effect of fiscal balance fund on income inequality in West Kalimantan by using spatial econometric, and (3) other factors influencing income inequality in West Kalimantan. 


\section{METHOD}

Secondary data used in the study was taken from the official document of Directorate General of Fiscal Balance of The Ministry of Finance (DJPK Kemenkeu). It was Central Government Financial Report in 2010-2018. In addition, the official document of Central Bureau of Statistics of West Kalimantan Province included Local Gross Domestic Product (GDP) of Districts/Cities in West Kalimantan, Statistical Yearbook of West Kalimantan, Labor Force Situation in 2010-2017 and several documents related to this study. The secondary data was panel data, integration of cross section data of 14 districts/cities in West Kalimantan and time series data from 2010 to 2018. The secondary data were produced and analysed by using statistic spatial econometric tool and method. Stata software version 14.2 was used in data processing to produce a more reliable data processing.

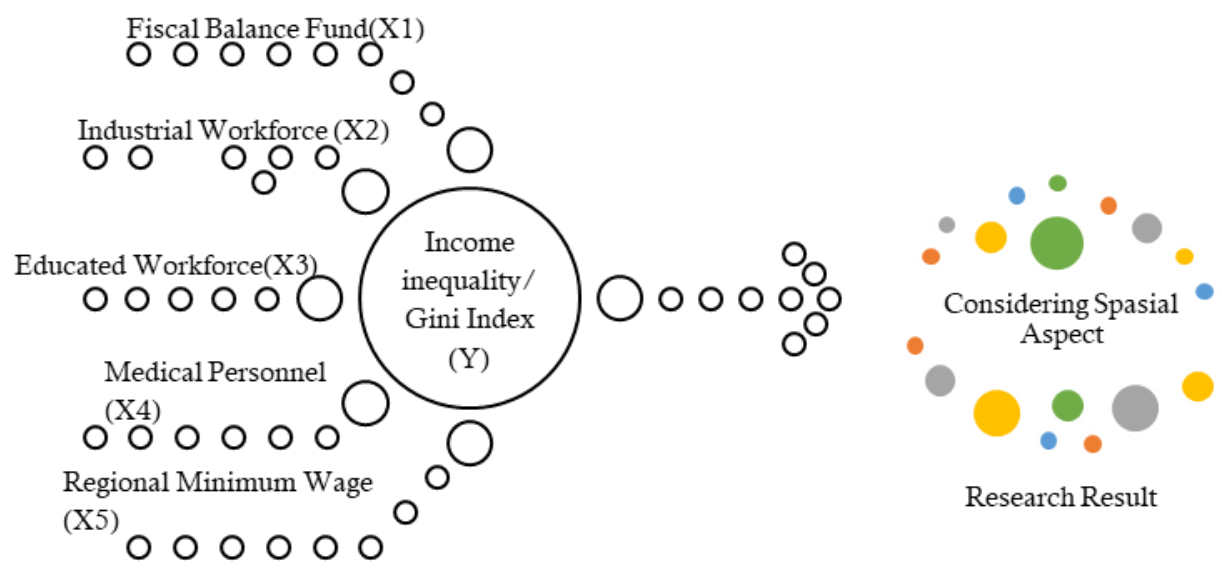

Figure 2. Framework

On the basis of literature review, the hypothesis of the study was the probability of $\mathrm{H}_{1}$ : spatial aspect has impact on West Kalimantan's income inequality, $\mathrm{H}_{2}$ : Fiscal balance fund influences West Kalimantan's income inequality, $\mathrm{H}_{3}$ : other factors are industrial workforce, educated workforce, medical personnel, and regional minimum wage, partially influence West Kalimantan's income inequality.

Williamson index and Gini index were used to measure the level of income inequality in West Kalimantan in this study. Williamson index was used to see the disparity of income distribution by using GDP per capita as the indicator on the basis of constant price and total population in provincial level and districts/cities. To determine the number of income inequality, the researchers used Williamson index with the following formulation:

$$
I_{w}=\frac{\sqrt{\sum\left(y_{i}-y\right)^{2}(f i / n)}}{Y}
$$

The formulation above includes $I_{W}$ which means Williamson Index, $y_{i}$ is income per capita constant for districts/cities to $i, y$ is income per capita constant for West Kalimantan, $f_{i}$ is total population of districts/cities to $i$, while $n$ is total population of West Kalimantan. The result criteria used in the study is Williamson index $>1$ which indicates a very high inequality; Williamson index 0,7 - 1 indicates a high inequality; Williamson index 0,4 0,69 indicates medium inequality; and Williamson index $<0,39$ indicates low inequality. 
In this study, the income inequality using Gini index did not use calculation because the data was available and taken from the report of Central Bureau of Statistics of West Kalimantan. Gini index of every district/city was used as endogenous variable in partial regression analysis. According to the regulation of the Minister of Labor and Transmigration of the Republic of Indonesia Number PER.25/MEN/IX/2009 on The Level of Transmigration Settlement Development, Gini index is the standard of income equalization which calculated according to income class in ten income class (decille). The formulation of Gini index is as follows:

$$
G R=1-\sum f_{i}\left[Y_{i}+Y_{i-1}\right]
$$

It explains that GR stands for Gini Ratio, $f_{i}$ is the percentage (\%) of class income earner in -i, $Y_{i}$ is the cumulative amount (\%) of class income in $-i$. The criteria of result are Gini Ratio $>0,5$ indicates high inequality; Gini Ratio $0,4-0,5$ indicates medium inequality; Gini Ratio $<0,4$ indicates low inequality. The value of Gini Ratio lies on between zero to one. If $\mathrm{GR}=0$, income inequality is perfectly even, it means that everyone acquires equal income. If GR $=1$, income inequality is imperfect, or the income is only acquired only by one person or one group.

\section{Spatial Econometric Panel Data}

Spatial panel is special panel case in which data is observed in two dimensions; crossing spatial unit and over time. Panel data model has been widespread through the availability of database containing many observations on individual unit, for example a country which is continuously updated and has administrative report, periodic national survey, and repeated measurement from several phenomenon in various moments (Arbia, 2014). The method of spatial econometric analysis of panel data attempted to look for and bring out spatial dependence in an econometry model, it is simple pooled linear regression with the special effect of spatial without spatial interaction as follows (Elhorst, 2010):

$$
y_{i t}=X_{i t} \beta+\mu_{i}+\varepsilon_{i t}
$$

According to the formulation, $i$ represents the index of cross-sectional dimension (sectional unit), with $i=1, \ldots, N$, and $t$ is time dimension index (time period), with $t=1$, .., T. $y_{i t}$ is observation on the dependent variable at $i$ and $t, \mathrm{X}_{\mathrm{it}}$ is one of row vectors of observation $k$ on the independent variable, and $\beta$ is the compatibility of $k$ fixed vector of unknown parameter. $\varepsilon_{i t}$ independently and identically is the value for error distribution for $I$ and $t$ with zero mean and the variant $\sigma^{2}$,, while $\mu_{i}$ indicates the effect of spatial specific spatial. The standard reason of spatial specific effect is to monitor all variables of panel data which can produce an estimation bias in cross-sectional study.

In determining the interaction between the spatial units, the model can include dependent variable of spatial lag or spatial autoregressive process in the error term, which respectively known as lag spatial and spatial error model. Lag spatial model stated that the dependent variable depends on the observed dependent variable in the neighboring unit and on the observed local characteristic set. 


$$
y_{i t}=\delta \sum_{j=1}^{N} W_{i j} y_{j t}+X_{i t} \beta+\mu_{i}+\varepsilon_{i t}
$$

The symbol $\delta$ is the coefficient of autoregressive spatial (spatial lag parameter), $W$ is the spatial weighted matrix with diagonal elements which is equal to zero. Meanwhile, spatial error model determines the correlation between spaces in error value. The model describes spatial linkages on error random; thus, $\left(W^{\varepsilon}\right)$ is composed as the independent variable. The spatial weighted matrix $(W)$ can be taken according to the information on the distance from one region to another (neighborhood).

The method used to define the contiguity between regions in the study was queen contiguity. Contiguity is two spatial units having joint limit which length is not equal to zero. The criteria of queen contiguity defines the neighbor as the spatial units share the same edges and angles or it considers the direct neighbor (Anselin \& Rey, 2014). In practice, the construction of spatial weight from data geometry cannot be done by visual inspection or manual calculation, unless in the most trivial situation. It is to assess whether two contiguous polygon requires the use of spatial data structure which related to polygon location and setting. Therefore, the researchers used GeoDa software version 1.14 in calculating the weight matrix.

In this study, the weight matrix of each district/city in West Kalimantan was used for the spatial econometric regression and to calculate Moran's I which was the initial step before regression, it analyzed the characteristics of regional group (spatial linkage) by using the following statistic test (Anselin \& Rey, 2014).

$$
I=\frac{\Sigma_{i} \Sigma_{j} w_{i j} z_{i} \cdot z_{j} / S_{0}}{\Sigma_{i} z_{i}^{2} / n}
$$

The symbol $w_{i j}$ is the spatial element of weight matrix, $S_{0}=\Sigma_{i} \Sigma_{j} w_{i j}$ is the sum of weight, and $n$ is the number of observations. The score of Moran's I index is on the range $-1<\mathrm{I}<1$. If $I$ is significant positive, thus the territorial grouping which has similar characteristics (a region with a high Gini ratio index surrounded by the neighbor with a high Gini ratio index, or vice versa) will be occurred. Meanwhile, if $I$ is significant negative, thus the territorial grouping with the different characteristics (a region with a high Gini ration index surrounded by the neighbor with a low Gini ratio index, or vice versa). In the meantime, if $I$ is zero, thus there is no spatial linkage between the regions.

Income inequality influenced by some factors, especially different demographic condition, concentration of regional economic activities, allocation and development, and government regulation; thus, the model design in the study was as follows:

Inequality $=f($ Balance, Industry, Educated, Medic, Regional Minimum Wage/UMR)

The researchers adapted two research models of (Hasna, 2013), they are Spatial Autoregressive (SAR) model and Spatial Error Model (SEM) which explain as follows

Model Spatial Lag

$$
\begin{gathered}
\text { rgini }_{i t}=\rho W \text { rgini }_{j t}+\beta_{1} \text { Balance }_{i t}+\beta_{2} \text { Industry }_{i t}+\beta_{3} \text { Educated }_{i t}+\beta_{4} \text { Medic }_{i t} \\
+\beta_{5} U M R_{i t}+\mu_{i}+\varepsilon_{i t}
\end{gathered}
$$




\section{Spatial Error Model}

rgini $_{i t}=\beta_{1}$ Balance $_{i t}+\beta_{2}$ Industry $_{i t}+\beta_{3}$ Educated $_{i t}+\beta_{4}$ Medic $_{i t}+\beta_{5} U M R_{i t}+\phi_{i t}$ $\phi_{i t}=\lambda w_{i j} \phi_{j t}+\varepsilon_{i t}$

The description of each part in the model is as follows:

\begin{tabular}{|c|c|c|}
\hline rgini $_{i t}$ & $=$ & Gini ratio index represents income inequality of districts/cities \\
\hline$\rho, \lambda$ & & Autoregressive spatial coefficient \\
\hline$w$ & $=$ & weight matrix \\
\hline Balance $_{i t}$ & $=$ & $\begin{array}{l}\text { The sum of General Allocation Fund (DAU), Special Allocation Fund } \\
\text { (DAK), and Revenue Sharing Fund (DBH) of every district/city in } \\
\text { hundreds of billions of Rupiahs. }\end{array}$ \\
\hline Industry $_{i t}$ & $=$ & $\begin{array}{l}\text { The percentage of workforce amount in person over } 15 \text { years old in } \\
\text { industrial sector in each district/city. }\end{array}$ \\
\hline Terdidik $_{i t}$ & $=$ & $\begin{array}{l}\text { The percentage of workforce graduated from public or vocational high } \\
\text { school, Diploma and bachelor's degree in every district/city. }\end{array}$ \\
\hline Medis $_{i t}$ & $=$ & The amount of health workers in person according to district/city. \\
\hline$U M R_{i t}$ & $=$ & $\begin{array}{l}\text { Minimum wage according to the necessity of decent living standard } \\
\text { calculated from hundreds of thousands of Rupiahs. }\end{array}$ \\
\hline
\end{tabular}

Estimation Technique

There are several estimation methods of spatial panel model that had been proposed by another researcher. Generally, the estimation method consists of two categories (Belotti et al., 2017), they are i) Generalized Method of Moments (GMM), and; ii) Quasi Maximum Likelihood (QML) estimator. The estimation technique of the study was Quasi Maximum Likelihood (QML) because the calculation time required to do full maximum likelihood estimation can be reduced by transforming the variable which enables the function of concentrated likelihood; thus, the estimation can be done in two ways.

\section{The Selection of the Best Model}

In selecting the best model, Lagrange Multiplier was done to determine the best model between spatial lag and spatial error according to the criteria for comparison of model goodness between spatial and pooled/common models. Lagrange multiplier test and Robust Lagrange Multiplier test were used to select spatial model which fit to describe the actual data condition.

Lagrange Multiplier test for spatial lag model

Lagrange multiplier test was used to find out whether the coefficient value of WY is equal to zero. If the coefficient value of WY is not equal to zero significantly, thus the spatial lag model is better to be used than common model. The hypothesis was as follows:

$\mathrm{H}_{0}: \rho=0$, (pooled model is better to be used)

$\mathrm{H}_{1}: \rho \quad \neq 0$, (spatial lag model is better to be used)

Lagrange Multiplier test for spatial error model

Lagrange Multiplier was used to find out whether the coefficient value of $w^{\varepsilon}$ is equal to zero. If the coefficient for $w^{\varepsilon}$ is not equal to zero significantly, thus the spatial error model is better to be used than pooled. The hypothesis was as follows: 
$\mathrm{H}_{0}: \lambda=0$, (pooled model is better to be used)

$\mathrm{H}_{1}: \lambda \neq 0$, (spatial error model is better to be used)

If Lagrange Multiplier test concludes that the best model is lag model and error model (both significant test rejects $\mathrm{H}_{0}$ ), thus an advanced test is necessary. The advanced test is called Lagrange Multiplier Robust test. The test has the same benefit, it is to find out whether the coefficient value of WY and $w^{\varepsilon}$ is equal to zero or not. Therefore, the hypothesis used in the test is identical to Lagrange Multiplier test. The difference is only the statistic test.

Differently, to test the properness of panel model usage between fixed effect and random effect, Hausman test was used. The basis of Hausman test was to find out whether the individual effect occurs on error or intercept. The hypothesis used in Hausman test was as follows:

$\mathrm{H}_{0}$ : Probability value $>\alpha$ (model random effect)

$\mathrm{H}_{1}$ : Probability value $<\alpha$ (model fixed effect)

\section{FINDING AND DISCUSSION}

According to total population and Local Gross Domestic Product (GDP) per capita of district/city in West Kalimantan in 2010-2018, income inequality can be calculated using Williamson index as shown in Figure 3. The income inequality in West Kalimantan was 0.29 which showed low inequality between district/city in West Kalimantan. In other words, income was relatively equal per capita. Income inequality in West Kalimantan using Williamson Index tended to be constant during 2010-2018. The highest inequality in West Kalimantan was in 2010, it was 0.43 because Pontianak had the most striking income inequality rather than another district/city. Pontianak city as the capital city of West Kalimantan province had GDP per capita at 2000 highest constant price in 2010, it was Rp11.935.153.93 than the average GDP per capita constant of West Kalimantan which was Rp6.081.615.64. Therefore, it contributed greatly to the economy of West Kalimantan. Pontianak city is a region with the highest GDP per capita yet the highest income inequality, it means the city has not been able to provide equal welfare to its inhabitants. It is surely not in accordance with what the government expects. The results were in line with the research result of Kurniasih (2013) stating that the inequality occurs in the level of low income per capita, thus the low inequality condition actually does not represent public welfare completely.

Inequality between regions in West Kalimantan is relatively low according to the average index between 2011 and 2018. Only Pontianak city that had index the average inequality index 0.207 , but it was still under the average inequality index of West Kalimantan which was 0.287. Sambas and Kapuas Hulu districts were two districts which had the lowest income inequality in West Kalimantan. GDP per capita of Sambas district (Rp23.432.707,05) was close to the average GDP per capita of West Kalimantan (Rp23.779.134.16) in 2017, and GDP per capita of Sambas district (Rp24.476.135,40) was also close to West Kalimantan (Rp24.715.228,62) in 2018. Therefore, Sambas district hardly experienced income inequality. 


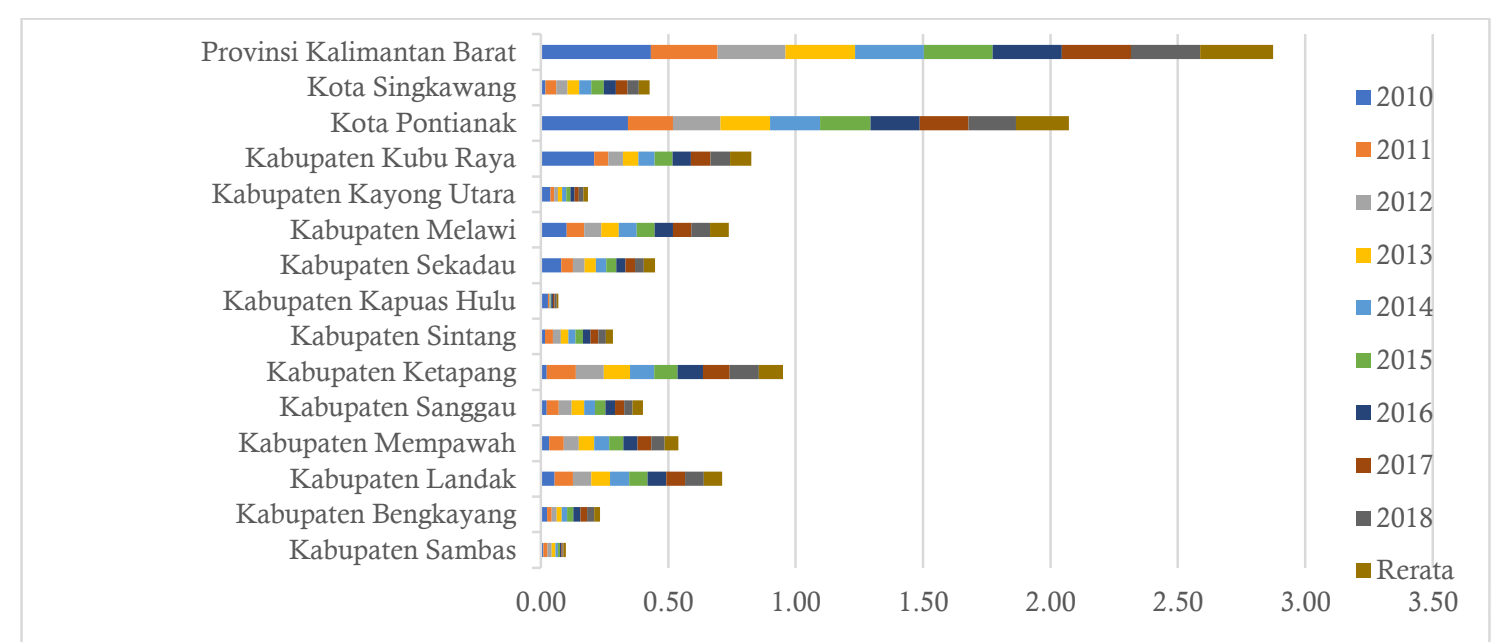

Figure 3. Williamson Index (Central Bureau of Statistic of West Kalimantan Province, 2010)

The province which has districts/cities GDP per capita is close to the average of provincial GDP per capita causes income inequality, it is the Williamson index closes to zero or almost no inequality at all, for example Kapuas Hulu district. Total population as the divider also influences income inequality value. Sambas district has the average population of $11 \%$ of the total population on West Kalimantan in 2017-2018, while Kapuas Hulu district has the average population of $5 \%$ of the total population on West Kalimantan in 2012-2015. GDP per capita constant and total population become the main determinants of income inequality in districts/cities.

\section{The Calculation of Moran's I}

In the initial step, before doing the regression in the model, the calculation of Moran's I was used to find out the existence of spatial autocorrelation on Y variable (Gini index). The result of weight matrix, first of all, had to be known. The calculation of weight matrix in West Kalimantan showed Ketapang district as the district which has the most neighbors, it has seven neighbors which weight is 0.14 . The more the neighbors, the smaller the weight value. The district with a small amount of neighbor will have a large weight score. Kapuas Hulu district only has one close neighbor with weight score is 1 . The weight matrix, afterward, was used to calculate Moran's I.

The result of Moran's I calculation for Gini index 2010-2018 showed the value of Moran's I is $-0.029,-0.049,0.071,0.266,-0.032,-0.128,-0.106,0.048$, and -0.23 . The district which had the significant value of Moran's I was Bengkayang district ( $p$-value $=0.001$ ) and Kayong Utara district ( $p$-value $=0.05)$ in 2010, while Kayong Utara district $(p$-value $=0.05)$ in 2012, Sintang district Sintang $(p$-value $=0.01)$ in 2013, Melawi district $(p$-value $=0.05)$ and Kapuas Hulu ( -value $=0.001)$ in 2018 .

The district/city with non-significant value of Moran's I indicates no linkage indication (spatial autocorrelation) between one region and the neighbor. On the contrary, if the districts/cities have the significant value of Moran's I, it indicates linkage indication (spatial autocorrelation) between one region and the neighbor. The negative significant 
indicates the territorial grouping with different characteristics (a region with a high Gini ratio index surrounded by neighbors with low Gini ratio). Melawi district has three neighbors: Sintang district, Ketapang district and Central Government Province. Meanwhile, Kapuas Hulu has four neighbors: Malaysia, Sintang district, Murung Raya district of Central Kalimantan Province and West Kutai district of East Kalimantan Province. Central Kalimantan and East Kalimantan has a lower Gini index than West Kalimantan province as an observation area because the income of West Kalimantan's resident per capita is lower than the residents of another Kalimantan. Since the different geographical distribution of natural resources, public infrastructure and economic activities, spatial gap cannot be avoided (Akita \& Miyata, 2017).

\section{The Test Result of the Best Model Selection}

In order to select the best model between spatial lag and spatial error, Lagrange Multiplier (LM) test was done. The test result of LM and Robust LM showed that the spatial lag $(p$-value $=0.067)$ was better than pooled/common model because it was significant on $\alpha=0.10(10 \%)$, while spatial error model ( $p$-value $=0.124)$ could not be used because it was non-significant on either $\alpha=0,1(10 \%)$ or $0.05(5 \%)$. From Moran's I test which was to find out the spatial correlation and Lagrange Multiplier (LM) test to find out spatial dependence, it can be concluded that spatial autocorrelation or spatial lag dependence generally on the research model is formed because of value $<\alpha=10 \%(0.1)$.

Table 2. Lagrange Multiplier Test

\begin{tabular}{lrrr}
\hline Test & Statistic & df & p-value \\
\hline Spatial error: & & & \\
Moran's I & 3.358 & 1 & 0.001 \\
Lagrange multiplier & 2.365 & 1 & 0.124 \\
Robust Lagrange multiplier & 0.96 & 1 & 0.327 \\
Spatial lag: & & & \\
Lagrange multiplier & 3.353 & 1 & 0.067 \\
Robust Lagrange multiplier & 1.948 & 1 & 0.163 \\
\hline
\end{tabular}

The selection of fixed effect or random effect model to fit to estimate spatial model lag was the next step in the study. From Hausman test, it can be concluded that data for using SAR panel model was failed to fulfill asymptotic assumption. It is a general issue occurred in the spatial panel data model, especially in the small sample (Belotti et al., 2017). See attachment 1.

The problematic effort to expand basic spatial regression model in order to include a more complicated dependent structure because of lack of complete understanding of basic spatial regression (J. P. LeSage \& Pace, 2011). The selection of the best basic spatial model is necessary to acquire the best research result. By using strategy explained in J. LeSage \& Pace (2009) and Elhorst (2010), the researchers should begin with Spatial Durbin Model (SDM) as the general specification and alternative test (Belotti et al., 2017). The model is the generalization of spatial autoregressive model (SAR) model which includes weighted 
spatial independent variable as an explanatory variable. Spatial Durbin Model includes spatial lag for dependent and independent variables to cope with spatial dependent issue. According to Hausman test for SDM model, it can be concluded that fixed effect is better than random effect. It is in line with Monte Carlo's experiment which showed good sample performances using fixed effect panel data model (Elhorst, 2014). In other words, null hypothesis was rejected because the statistic test $x^{2}$ was 12.13 and $p$-value was less than $\alpha=$ $0.01(1 \%)$. See attachment 2 .

Hypothesis and Significance Test on the Model of Spatial Durbin Model with Fixed Effect After two steps of the best model selection, thus the hypothesis and significance test on the chosen model, namely Spatial Durbin Model with fixed effect, was done. The result of model estimation through data procession using stata version 14.2 is presented in Table 3 .

Table 3. The Estimation Result of Spatial Durbin Model with Fixed Effect

\begin{tabular}{lrcccc}
\hline & Gini & Coefficient & Std. Err. & $\mathrm{z}$ & $\mathrm{P}>|\mathrm{z}|$ \\
\hline Main & & & & & \\
& Balance Fund & $-1.03 \mathrm{e}-13$ & $5.13 \mathrm{e}-14$ & -2.00 & 0.046 \\
& Industry & .01849 & .1519524 & 0.12 & 0.903 \\
& Educated & -.013642 & .071658 & -0.19 & 0.849 \\
& Medic & .0176619 & .0668223 & 0.26 & 0.792 \\
& UMR & $-3.99 \mathrm{e}-08$ & $1.89 \mathrm{e}-08$ & -2.10 & 0.035 \\
\hline Spatial & rho & -.2592896 & .1429023 & -1.81 & 0.070 \\
\hline Variance & sigma2_e & .0014382 & .000183 & 7.86 & 0.000
\end{tabular}

Income inequality model in West Kalimantan is as follows:

$$
\begin{aligned}
\text { rgini }_{i t}=- & 0.2592896 \text { W rgini }_{j t}-0.000000000000103 \text { Perimbangan }_{i t} \\
& +0.01849 \text { Industri }_{i t}-0.013642 \text { Terdidik }_{i t}+0.0176619 \text { Medis }_{i t} \\
& -0.0000000399 U M R_{i t}
\end{aligned}
$$

The estimation result of Spatial Durbin Model with fixed effect indicated that the fiscal balance fund and regional minimum wage were significant on $\alpha=0.05(5 \%)$ in influencing the income inequality. Meanwhile, the variables of industrial workforce, educated workforce and medical personnel were non-significant in influencing the income inequality.

The Impact of Spatial Aspect on the Income inequality $\mathrm{H}_{1}$ : Spatial Aspect has impact on income inequality in West Kalimantan. $\left(\mathrm{H}_{0}\right.$ rejected, $\mathbf{H}_{1}$ is not rejected)

The coefficient of spatial rho from the regression result of Spatial Durbin Model with fixed effect is -0.2592896 with the probability is 0.070 significant on $\alpha=0.10(10 \%)$ which indicates spatial aspect has negative impact significantly on the income inequality in West Kalimantan. The dimension of spatial interaction between one district/city with its district/city of the neighbor was -0.2592896 . The value of spatial interaction was range 
between 0 and 1 , thus the value -0.2592896 indicated a relative low value because it did not reach $50 \%$.

The negative value showed that the territorial grouping with different characteristics (a region with a high Gini ratio index surrounded by the neighbor with low Gini ratio index, or vice versa). The spatial aspect influences the decrease of income inequality in West Kalimantan. The spatial interaction which has a significant impact on the income inequality could not be analyzed by conventional regression. The spatial effect was included in the analysis as it contributed to solve the econometric problem as the violation of sphericity assumption in convergent model (Soundararajan, 2013). Spatial data usually violates the assumption that every independent observation of other observation was done using common regression. It has econometric implication for estimation quality and conclusion taken from non spatial regression model (J. P. LeSage, 2014).

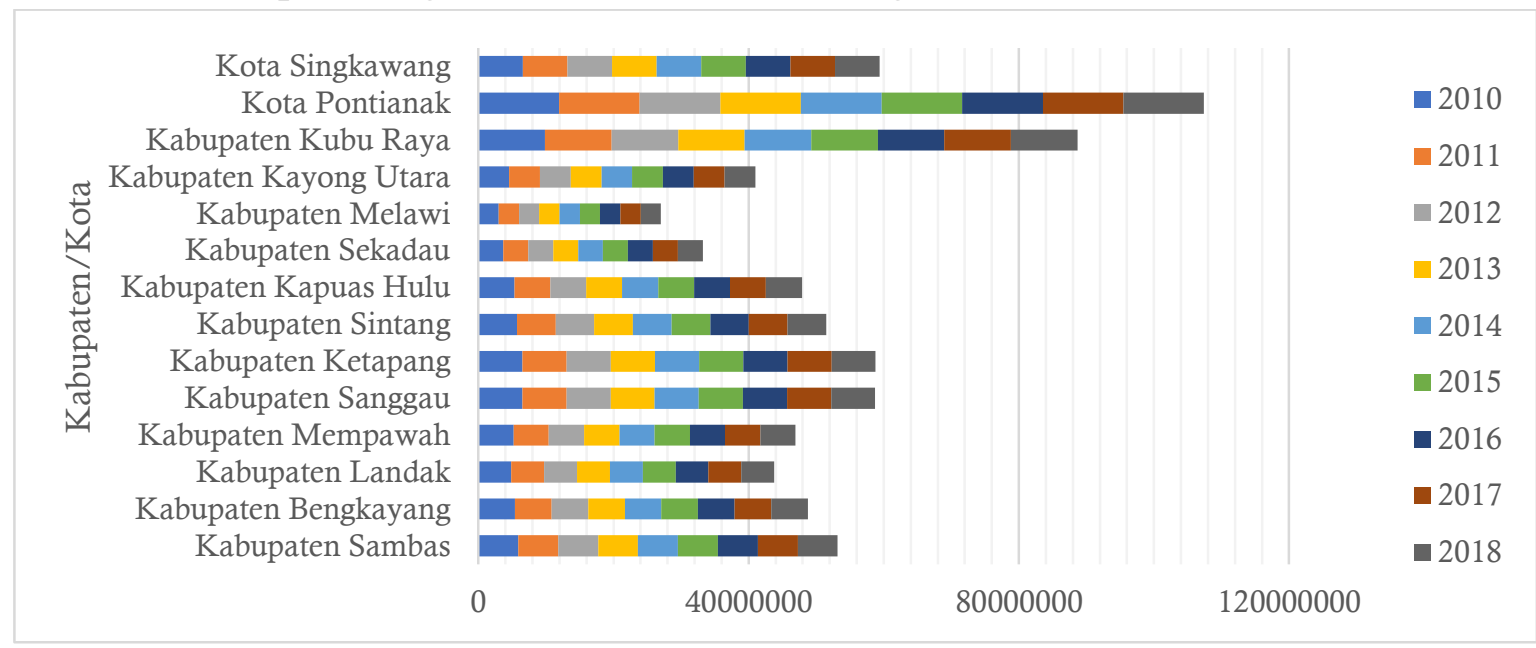

Figure 4. GDP per capita constant (Central Bureau of Statistics of West Kalimantan, 2018).

The income disparities are highly determined by GDP per capita The proof shows the negative significant spatial aspect seen in Figure 4. Pontianak City as the capital city of West Kalimantan Province has the highest GDP per capita. The research of Brasili et al (2013) showed GDP adhere to spatial pattern, which the highest value found in the core area of geographic scope proved that the hypothesis of economy and geography is inter-connected. There are a strong spatial autocorrelation on GDP per capita and income inequality (Gezycy, 2004).

The Effect of Fiscal Balance Fund on Income inequality

$\mathrm{H}_{2}$ : Fiscal balance fund has the impact on income inequality in West Kalimantan $\left(\mathrm{H}_{0}\right.$ is rejected, $\mathbf{H}_{2}$ is not rejected)

Coefficient of fiscal balance fund from the regression result of Spatial Durbin Model with fixed effect is $-1.03 \mathrm{e}-13$ with the probability 0.046 significant on $\alpha=0.05(5 \%)$ indicates that the fiscal balance fund has a significant negative impact on income inequality in West Kalimantan. The negative mark indicates that the increase of fiscal balance fund will cause the decrease of income inequality index, and vice versa. 
Fiscal balance fund is the largest section of fund transfer from central to regional government coming from the State Budget to facilitate regional needs and as a form of decentralization. Fiscal balance form includes General Allocation Fund (DAU), Special Allocation Fund and Sharing Revenue (DBH) coming from revenue of taxes, natural resources and customs.

According to Directorate General of Fiscal Finance as written in the Regulation of the Minister of Finance Number 30/PMK.07/2018 on the Detail of Revenue Sharing Fund of Customs of Tobacco Product in the Fiscal Year 2018, the allocation which West Kalimantan received was Rp7.405.187.00, and among Kalimantan provinces, it had the biggest allocation. Custom revenue especially in West Kalimantan since 2018 or the last one year of the observation year was $0.7 \%$ of total fiscal balance fund for every district/city, which previously came only from tax revenue and natural resources. Revenue sharing fund allocated to the regions based on the certain percentage figures (customs of tobacco, dried tobacco and human development index) for funding the regional needs in order to improve vertical balance between the central and regional level by regarding the potency of production region which West Kalimantan is the second largest producer in Indonesia. Revenue sharing fund influences regional income inequality significantly through economic growth variable.

The research has answered another research which stated that distribution of fund transfer did not reduce economic inequality between regions although disparity between provinces shows that it continues to decline. Gap reduction probably caused by the distribution of transferred fund which is bias to the area with low Human Development Index and another service indicator (Suratman, 2017). West Kalimantan's Human Development Index was 66.98 which ranked 30 of 34 provinces in Indonesia. Fiscal balance fund significantly influences regional income inequality, especially for the region with low Human Development Index.

Other Factors Affecting Income inequality

$\mathrm{H}_{4}$ : Other factors are industrial workforce, educated workforce, medical personnel and regional minimum wage partially affect income inequality in West Kalimantan.

$\left(\mathrm{H}_{0}\right.$ is not rejected, $\mathbf{H}_{3}$ rejected)

Coefficient of regression result of Spatial Durbin Model with fixed effect is 0.01849 ( $p$ value $=0.903)$ for the industrial workforce, $-0.013642(p$-value $=0.849)$ for the educated workforce, $0.0176619(p$-value $=0.792)$ for the medical personnel showed non-significant result. In other words, the industrial workforce, educated workforce and medical personnel did not have impact on income inequality index. Differently, the coefficient of regional minimum wage was $-3.99 \mathrm{e}-08$ with the probability was 0.035 significant to $\alpha=0.05(5 \%)$, it indicates that the regional minimum wage has significant negative impact on income inequality in West Kalimantan. Of four other factors, only regional minimum wage that has impact on income inequality in this research model. It also means that the increase of regional minimum wage will cause the decrease of income inequality, and vice versa. 
The average industrial workforce in West Kalimantan during 2010-2018 was Landak district with the lowest percentage (1.6\%), and Pontianak city as the highest percentage $(9.2 \%)$, and the average percentage in West Kalimantan was $6 \%$. It is because most of West Kalimantan's people are dominated by workers in agricultural sector. In line with the research of Laksono et al. (2018). that explains the growth of non-agricultural workforce does not affect income inequality level. Workers of processing industrial sector, in most of the provinces in Indonesia, receives real wages above regional minimum wage because most workers are laborers/employees of a company which has duty to provide real wages above regional minimum wage (Dewi, 2016).

The demographic condition includes population growth rate and structure, educational level and health, workforce condition and people's behavior can encourage income inequality. The test showed that the educated workforce does not have significant influence on income distribution in West Kalimantan because the comparison between the education level (General or Vocational High School, Diploma and bachelor's degree) of residents in each district/city and the working residents is only $12 \%$ to $30 \%$ for district, and $50 \%$ for Pontianak city. Overall, the educated workforce in West Kalimantan was only 26\%. Meanwhile, the average medical personnel in West Kalimantan in $2010-2018$ was $16 \%$ of the population needs. According to many researches and literature reviews stating that education is the determinant factor of workforce productivity. Education becomes an effective socio-economic balancer, its development becomes an urgent need in the provincial level(Nawaz-ul-huda et al., 2015). The region which has a good demography tends to have a high productivity which promotes investment, employment provision as well as economic growth. The improvement of free electricity and internet access is able to overcome spatial convergence, especially in urban area (Shilpi, 2013).

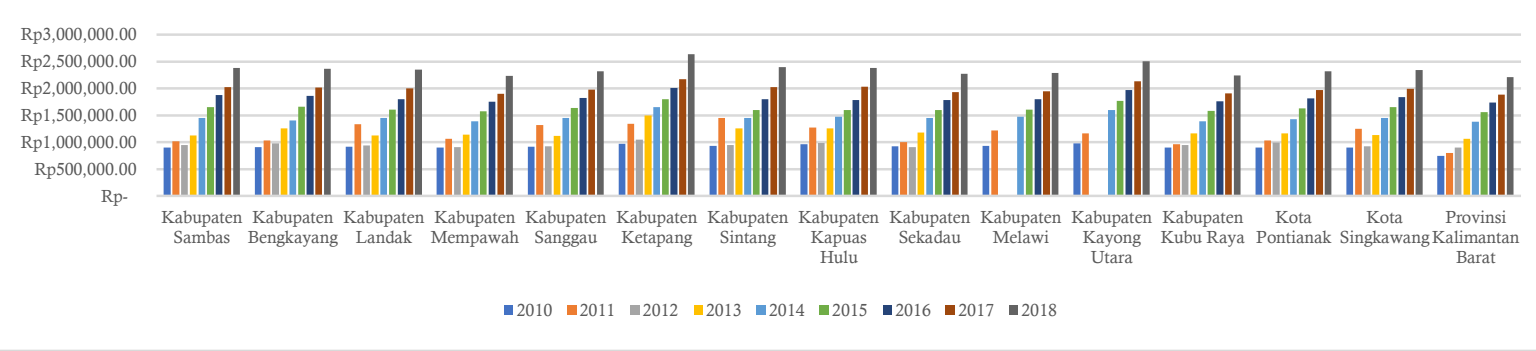

Figure 5. The average Decent Living Standard (Central Bureau of Statistics of West Kalimantan, 2018)

Minimum wage is based on decent living standard by regarding productivity and economic growth in which the percentage of increases in wage will highly depend on inflation. If a region can maintain a steady inflation and economic growth which significantly increases; thus, the minimum wage will also increase. The research has shown that when the minimum wage increases, regional income inequality decreases (negative correlation) as long as other economic factors are stable. Ketapang district provides the highest minimum wage compared to another region in West Kalimantan because the economic growth in Ketapang district in 2018 was the highest, it was $7.99 \%$ with Gini index was 0.29 , while the economic growth of West Kalimantan province was $5.06 \%$ with Gini index was 0.34 . 


\section{CONCLUSION}

Spatial aspect has a significant negative impact to the income inequality index of West Kalimantan. A regional grouping with dissimilar characteristics (a region with high Gini ratio surrounded by the neighbor with low Gini ratio, or vice versa). The spatial interaction has impact on the income inequality in West Kalimantan. The spatial aspect has influence on the decrease of income inequality in West Kalimantan. The fiscal balance fund has a significant negative impact on the income inequality index of West Kalimantan, it means that the increase of fiscal balance fund causes the decrease of income inequality index, and vice versa. Other factors which significantly has impact on income inequality is only Regional Minimum Wage, while the industrial workforce, educated workforce and medical personnel are not significant.

The study has provided academics with the understanding of the importance of spatial dependence in income inequality model because economic activity is always related to the neighbors. The study is expected to be able to evaluate the economic development pattern in West Kalimantan as a material for the government policy maker. The use of a more complicated yet systematic spatial model is able to prove better result than the use of conventional econometric model. Although the study has taken data from 9 years of observation, the researchers only found small number of samples for panel data of spatial model because West Kalimantan only has 14 districts/cities. The use of more exogenous and reliable variables in explaining the variant of income inequality is recommended to produce a more comprehension and unbiased research result.

\section{ACKNOWLEDGEMENT}

The researchers would like to thank Directorate of Research and Community Service, Deputy of Research and Development Strengthening of The Ministry of Research and Technology/National Research and Innovation Agency which funded the study under the research for lecturer (Penelitian Dosen Pemula) scheme.

\section{REFERENCES}

Akita, T., \& Miyata, S. (2017). Spatial Dimensions of Expenditure Inequality in A Decentralizing Indonesia. April 2017(720), 75-75. https://doi.org/10.1007/978-1-349-67278-3_116.

Amelia, A., \& Ekobelawati, F. (2019). Efektivitas Transfer Pusat Terhadap Perekonomian Kalimantan Barat. Buletin Studi Ekonomi, 23(1), 124-137. https://ojs.unud.ac.id/index.php/bse/article/view/47066.

Anselin, L., \& Rey, S. J. (2014). Modern Spatial Econometrics in Practice: A Guide to GeoDa, GeoDaSpace and PySAL. In Modern Spatial Econometrics in Practice: A Guide to GeoDa, GeoDaSpace and PySAL. https://sergerey.org/giasp16/pdfs/anselin_rey_weights.pdf.

Arbia, G. (2014). A Primer for Spatial Econometrics: With Applications in R. In PalgraveTexts in Econometrics (1st Editio). Palgrave Macmillan. https://doi.org/10.1057/9781137317940. 
Aritenang, A. F. (2014). The Spatial Effect of Fiscal Decentralisation on Regional Disparities: The Case from Indonesia. Indonesian Journal of Geography, 46(1), 1. https://doi.org/10.22146/ijg.4985.

Belotti, F., Hughes, G., \& Piano Mortari, A. (2017). Spatial Panel Data Models Using Stata. SSRN Electronic Journal, 17(1). https://doi.org/10.2139/ssrn.2754703.

Brasili, C., Bruno, F., \& Saguatti, A. (2013). A Spatial Econometric Approach to EU Regional Disparities Between Economic and Geographical Periphery. Statistica, 72(3), 299-316. https://doi.org/10.6092/issn.1973-2201/3649.

Dewi, V. N. (2016). Model Estimation For Spatial SUR Panel Data (Case Study Sectoral Employment Model in Indonesia) [Intitut Teknologi Sepuluh Nopember]. https://repository.its.ac.id/41723/1/1314201719-Master-Thesis.pdf.

Elhorst, J. P. (2010). Spatial Panel Data Models. In Handbook of Applied Spatial Analysis: Software Tools, Methods and Applications (pp. 377-378). https://doi.org/10.1007/978-3642-03647-7.

Elhorst, J. P. (2014). Matlab Software for Spatial Panels. International Regional Science Review, 37(3), 389-405. https://doi.org/10.1177/0160017612452429.

Gezycy, F. (2004). New Regional Definition and Spatial Analysis of Regional Inequalities in Turkey. Related to the Regional Policies of EU. 44th Congress of the European Regional Science Association: "Regions and Fiscal Federalism", 25th - 29th August 2004, Porto, Portugal, 25th-29th August 2004. http://hdl.handle.net/10419/116958.

Goerl, C.-A., \& Seiferling, M. (2014). Income Inequality, Fiscal Decentralization and Transfer Dependency. IMF Working Papers, $14(64), \quad 1$. https://doi.org/10.5089/9781484354711.001.

Hasna, S. (2013). Analisis Spasial Pengaruh Dana Perimbangan Terhadap Ketimpangan Pendapatan di Provinsi Jawa Timur Tahun 2008-2011. Jurnal BPPK, 06(02), 1-18. https://jurnal.bppk.kemenkeu.go.id/jurnalbppk/article/view/77.

Johansson, M. L. (2016). Intergovernmental Transfers and Regional Development Policies in Poland: Praxis and Problems. DPU Working Papers, 219-(4/201(188), 9-34. https://www.researchgate.net/publication/317313338_Intergovernmental_Transfers _and_Regional_Income_Inequalities_An_Empirical_Analysis_of_Uruguay.

Kurniasih, E. P. (2013). Ketimpangan Wilayah di Provinsi Kalimantan Barat Suatu Kajian terhadap Hipotesis Kuznet. Eksos, 9(1), 36-48. http://repository.polnep.ac.id/xmlui/handle/123456789/322.

Laksono, H., Rustiadi, E., \& Siregar, H. (2018). Spillover Spasial Negatif Pertumbuhan Ekonomi Antar Kabupaten/Kota Di Provinsi Jawa Timur. Tataloka, 20(3), 266. https://doi.org/10.14710/tataloka.20.3.266-277.

Leonel, M.-G., Rodríguez-Miranda, A., \& Castro-Scavone, P. (2016). Intergovernmental Transfers and Regional Income Inequalities: An Empirical Analysis of Uruguay. Hacienda Publica Espanola, 219(4), 9-34. https://doi.org/10.7866/HPE-RPE.16.4.1. 
LeSage, J. P. (2014). What Regional Scientists Need To Know About Spatial Econometrics. Review of Regional Studies, 44(1), 13-32. https://doi.org/10.2139/ssrn.2420725.

LeSage, J. P., \& Pace, R. K. (2011). Pitfalls in Higher Order Model Extensions of Basic Spatial Regression Methodology. Review of Regional Studies, 41(1), 13-26. http://journal.srsa.org/ojs/index.php/RRS/article/download/39/205.

LeSage, J., \& Pace, R. K. (2009). Introduction to Spatial Econometrics. In Introduction to Spatial Econometrics. https://doi.org/10.1111/j.1467-985x.2010.00681_13.x.

Masaki, T. (2018). The Impact of Intergovernmental Transfers on Local Revenue Generation in Sub-Saharan Africa: Evidence from Tanzania. World Development, 106, 173-186. https://doi.org/10.1016/j.worlddev.2018.01.026.

Muñoz, A. F., Radics, G. A., \& Bone, C. (2016). Subnational Fiscal Disparities and Intergovernmental Transfers in LAC. Hacienda Publica Espanola, 219(4), 35-66. https://doi.org/10.7866/HPE-RPE.16.4.2.

Nawaz-ul-huda, S., Burke, F., \& Azam, M. (2015). Socio-economic Disparities in Balochistan, Pakistan - A Multivariate Analysis. Geografia : Malaysian Journal of Society and Space, 7(4), 38-50. https://core.ac.uk/download/pdf/11492148.pdf.

Nolan, B., Rahbari, E., Matteo, R., Rivera, L. V., \& Nabarro, B. (2017). Inequality and Prosperity in the Industrialized World: Addressing a Growing Challenge. Oxford Martin School \& Citi, September. https://www.oxfordmartin.ox.ac.uk/downloads/Citi_GPS_Inequality.pdf.

Shilpi, F. (2013). Understanding the Sources of Spatial Disparity and Convergence : Evidence from Bangladesh. World Bank Let's Talk Development, June. https://papers.ssrn.com/sol3/papers.cfm?abstract_id=2287052.

Soundararajan, P. (2013). Regional Income Convergence in India: A Bayesian Spatial Durbin Model Approach. SSRN Electronic Journal, 1-15. https://doi.org/10.2139/ssrn.2228487.

Suratman, E. (2017). Dana Transfer dan Kesenjangan Wilayah. Kompak, September. https://www.kompak.or.id/storage/app/media/Publication/4_catatan_kebijakan/b rief-dana-transfer-10101.pdf.

Wardhana, A., Fauzan, A., \& Bustaman, A. (2018). Transfer Pemerintah Pusat dan Ketimpangan Pendapatan Kabupaten dan Kota di Jawa Barat (Pertama). BUDHI MULIA, cv. http://digilib.unimed.ac.id/28207/. 


\title{
Attachment 1. Output of STATA Hausman Test of SAR Fixed Effect and Random Effect
}

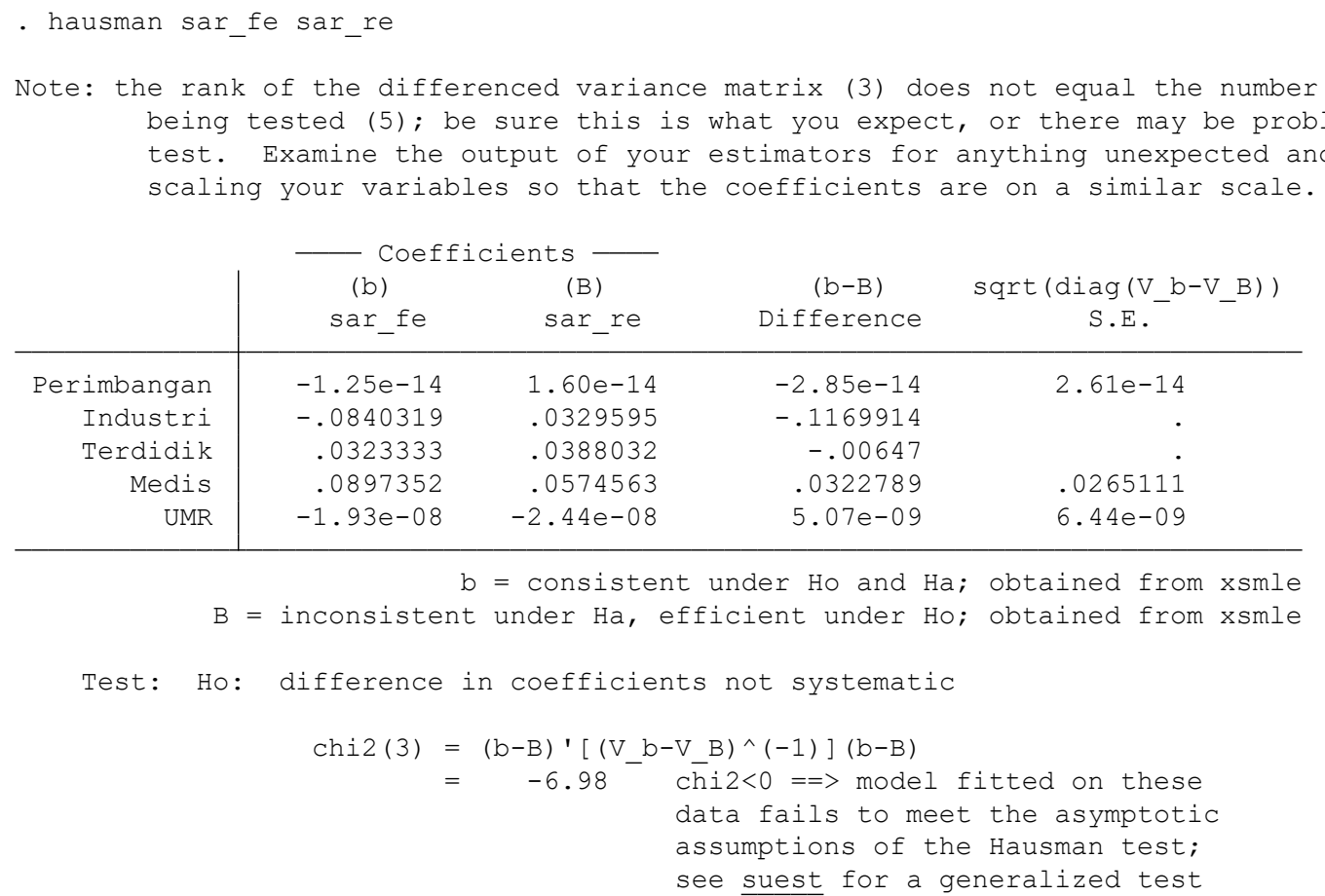

\begin{tabular}{|c|c|c|c|c|}
\hline & \multicolumn{2}{|c|}{$\longrightarrow$ Coefficients -} & \multirow[b]{2}{*}{$\begin{array}{c}(\mathrm{b}-\mathrm{B}) \\
\text { Difference }\end{array}$} & \multirow[b]{2}{*}{ 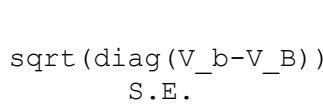 } \\
\hline & $\begin{array}{c}\text { (b) } \\
\text { sar fe }\end{array}$ & $\begin{array}{c}\text { (B) } \\
\text { sar re }\end{array}$ & & \\
\hline Perimbangan & $-1.25 e-14$ & $1.60 e-14$ & $-2.85 e-14$ & $2.61 e-14$ \\
\hline Industri & -.0840319 & .0329595 & -.1169914 & . \\
\hline Terdidik & .0323333 & .0388032 & -.00647 & . \\
\hline Medis & .0897352 & .0574563 & .0322789 & .0265111 \\
\hline UMR & $-1.93 e-08$ & $-2.44 e-08$ & $5.07 e-09$ & $6.44 e-09$ \\
\hline
\end{tabular}

$\mathrm{b}=$ consistent under $\mathrm{Ho}$ and $\mathrm{Ha}$; obtained from xsmle $\mathrm{B}=$ inconsistent under Ha, efficient under Ho; obtained from xsmle

Test: Ho: difference in coefficients not systematic

\section{Attachment 2 Output of STATA Hausman Test of SDM fixed and random effect}

\author{
. hausman sdm_fe sdm_re \\ Note: the rank of the differenced variance matrix (3) does not equal the number of coefficients \\ scaling your variables so that the coefficients are on a similar scale.

\begin{tabular}{|c|c|c|c|c|}
\hline & \multicolumn{2}{|c|}{$\longrightarrow$ Coefficients -} & \multirow[b]{2}{*}{$\begin{array}{c}(b-B) \\
\text { Difference }\end{array}$} & \multirow[b]{2}{*}{$\begin{array}{c}\operatorname{sqrt}\left(\operatorname{diag}\left(V_{-}{ }_{b}-V_{-} B\right)\right. \\
\text { S.E. }\end{array}$} \\
\hline & $\begin{array}{l}\text { (b) } \\
\text { sdm_fe }\end{array}$ & $\begin{array}{l}\text { (B) } \\
\text { sdm_re }\end{array}$ & & \\
\hline Perimbangan & $-1.03 e-13$ & $1.10 e-14$ & $-1.14 e-13$ & $4.81 e-14$ \\
\hline Industri & .01849 & .2650949 & -.2466049 & .0754393 \\
\hline Terdidik & -.013642 & .0421285 & -.0557704 & .0240891 \\
\hline Medis & .0176619 & .0584824 & -.0408205 & .0395415 \\
\hline UMR & $-3.99 e-08$ & $-3.11 e-08$ & $-8.72 e-09$ & . \\
\hline
\end{tabular} \\ $\mathrm{b}=$ consistent under Ho and Ha; obtained from xsmle \\ $\mathrm{B}=$ inconsistent under Ha, efficient under Ho; obtained from xsmle \\ Test: Ho: difference in coefficients not systematic

\begin{tabular}{|c|c|}
\hline $\operatorname{chi2}(3)=$ & $=(\mathrm{b}-\mathrm{B})^{\prime} \cdot\left[\left(\mathrm{V}_{-} \mathrm{b}_{\mathrm{b}}-\mathrm{V}_{-} \mathrm{B}\right)^{\wedge}(-\right.$ \\
\hline & $=\quad 12 . \overline{1} 3$ \\
\hline Prob $>$ chi2 $=$ & $=0.0069$ \\
\hline
\end{tabular}
being tested (5); be sure this is what you expect, or there may be problems computing the test. Examine the output of your estimators for anything unexpected and possibly consider 